\title{
Apuntes acerca de la ironía y otras variantes humorísticas ${ }^{1}$
}

\author{
Grethel Ramirez
}

Universidad Nacional, Costa Rica

\section{RESUMEN}

La ironía como figura retórica es un asunto de particular riqueza en los estudios literarios. En este artículo se analiza un conjunto de causas que podrían explicar el concepto de ironía y sus correspondencias con la sátira, la parodia y la comicidad.

\section{Abstract}

Irony as a rhetorical figure is of particular interest in literary studies. Here a number of causes are analyzed which could explain the concept of irony and its correspondences with satire, parody and humor.

Palabras clave: Teoría literaria, estética, ironía, humor Keywords: Literary theory. esthetics, irony, humor

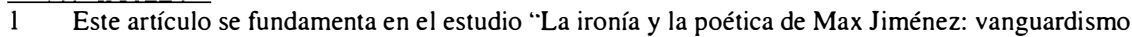
literario en Unos fantoches", que presentó su autora como tesis de grado, en la Escuela de Literatura y Ciencias del Lenguaje (UNA), en noviembre de 2005.

2 Correo electrónico: greravi@ costarricense.cr. 
"Somos Homo ludens así como somos Homo ridens. Y si nos reímos, sonreímos, bromeamos, planeamos sublimes estrategias de lo risible (y somos la única especie que lo hace, puesto que están excluidos de esta ventura los animales y los ángeles), es porque somos la única especie que. sin ser inmortal, sabe que no lo es. Y porque lo sabe es capaz de ironía".

Umberto Eco, Entre mentira e ironía

Pocos términos como la ironía han dado lugar a tantos escritos. En gran cantidad de ellos, más que una figura retórica se contempla una vertiente del carácter humano. Como consecuencia, se la ha fragmentado, se la ha convertido en anatema como a la condición humana misma. No obstante, a pesar de la dificultad de establecer una noción unitaria acerca de la ironía - muchas son las perspectivas, tantos los desacuerdos-, parece probable que la mejor vía esté en analizarla desde un enfoque lingüístico-literario ${ }^{3}$. La ironía es significativa para los estudios literarios; en las páginas que siguen se propone un conjunto de causas que podrían explicar su concepto y sus correspondencias con la sátira, parodia y comicidad.

La definición de ironía debe partir de la concomitancia enunciado-contexto de enunciación; por tanto, el sentido filosófico debe ceder, por el momento, su sitial. A continuación, se pretende establecer un panorama general al respecto. Al lado de la interrogante acerca de la ironía, habría que preguntarse por las relaciones que mantiene con la sátira, la parodia y el humor.

\section{En torno al concepto de ironía}

A lo largo de la historia, el concepto de ironía ha sido cultivado, primero, por la retórica; luego, por diversos estudios lingüísticos y literarios. Con el afán de delimitarla, Marchese y Forradellas, en su

$\overline{3}$ Sobre este particular. resulta útil la "Bibliografía sobre humor, ironía y parodia en teoría literaria y campos afines” elaborada por Lauro Zavala: Texto crítico, Nueva época, III, 4-5 (1997) 221-230. 
Diccionario de retórica, crítica y terminología literaria, afirman que la ironía:

[...] consiste en decir algo de tal manera que se entienda o se continúe de forma distinta a la que las palabras primeras parecen indicar: el lector, por tanto, debe efectuar una manipulación semántica que le permita descifrar correctamente el mensaje, ayudado bien por el contexto, bien por una peculiar entonación del discurso. La ironía presupone siempre en el destinatario la capacidad de comprender la desviación entre el nivel superficial y el nivel profundo de un enunciado. Particularmente importante es el uso de la ironía en el relato, cuando la superioridad del conocimiento del autor y del lector con relación a los personajes y a los acontecimientos en los que se ven mezclados permite disfrutar los subrayados irónicos escondidos entre los pliegues del discurso, los dobles sentidos, los equívocos o mal entendidos ${ }^{4}$.

Platas Tasende desarrolla una conceptualización que concuerda con la de Marchese y Forradellas, pues apunta que la ironía "consiste en la expresión de una idea mediante la contraria. En los textos, el significado real tiene poco que ver con el literal, por lo que debe contarse siempre con la competencia del receptor"s. Por su parte, Francisca Noguerol, al diferenciar lo alegórico de la ironía, considera a esta última "como un modo oblicuo de expresión esencialmente negativo, que refleja la distancia entre apariencia y realidad"6. Asimismo, Ducrot y Todorov la precisan, en algo restrictiva, como el "empleo de una palabra con el sentido de su antónimo"7.

$4 \quad$ Ángelo Marchese y Joaquín Forradellas, Diccionario de retórica, crítica y terminología literaria (Barcelona: Ariel, 2000) 221.

5 Ana María Platas Tasende, Diccionario de términos literarios (Madrid: Espasa, 2000) 404.

6 Francisca Noguerol Jiménez, La trampa en la sonrisa: sátira en la narrativa de Augusto Monterroso (Sevilla: Universidad de Sevilla-Secretariado de Publicaciones, 2000) 26.

7 Oswald Ducrot y Tzvetan Todorov, Diccionario enciclopédico de las ciencias del lenguaje (México: Siglo XXI, 1980) 319. 
Dentro de una línea de pensamiento semejante podría situarse la obra de Wayne Booth, quien, en La retórica de la ironía, anota a propósito de esto:

Algunos críticos han llegado a definir la ironía como una figura negativa, pues el primer paso para leerla es un "no" sonoro y un retroceso para descubrir alguna forma posible de dar sentido [...] al absurdo que se acaba de rechazar ${ }^{8}$.

En síntesis, la ironía implica un proceso de negación, por cuanto el receptor debe reconocer en ésta lo contrario a lo que se está diciendo, debe retroceder en su proceso de lectura para acceder al sentido. Al respecto, en "El concepto de ironía", Kierkegaard afirma que una determinación común a toda ironía radica en que "el fenómeno no es la esencia, sino lo contrario de la esencia"9 . De esta manera, la ironía no manifiesta literalmente una idea sino, de modo implícito, su antítesis. El problema que yace tras la ironía coincide con una de las grandes cuestiones acerca del lenguaje: ¿dónde está el sentido de nuestras palabras? Lo que la ironía muestra es el abismo de los signos; hacia lo que apunta, un problema de hermenéutica; lo que supone, un juego ante el mundo social.

Este desprecio hacia las comprensiones simples sobre el lenguaje se emparenta con la burla cómica; la risa se enfila contra los juicios poco profundos, contra la incapacidad de pensar con complejidad acerca del mundo. Freud, en El chiste y su relación con el inconsciente (1905), señala como uno de los más básicos procedimientos expresivos del chiste a la figuración por lo contrario ${ }^{10}$. Este tipo de construcción opera de manera semejante a la ironía, pues siempre manifiesta lo contrario de lo que dice literalmente. Dejemos pues, por el momento, este punto reservado para una discusión posterior.

$8 \quad$ Wayne C. Booth, Retórica de la ironía (Madrid: Taurus, 1989) 53.

9 Sören Kierkegaard, "Sobre el concepto de ironía", Revista de Occidente, 221 (1999) 74.

10 Sigmund Freud, El chiste y su relación con el inconsciente (Buenos Aires: Amorrortu, 1993) 67. 
Noguerol hace un recuento de la presencia de esta construcción discursiva en la producción simbólica de nuestro siglo y concluye que la ironía se revela como una constante en la literatura contemporánea; tal continuidad puede deberse a que permite una síntesis de dualidades. En las sociedades modernas se ha vuelto cada vez más relevante la necesidad de que los textos sean de carácter interrogativo: la caída de los grandes relatos (progresismo capitalista y socialismo, entre otros) ha provocado una especie de atomización del juicio; cada vez menos persisten las certidumbres y, con el crecimiento astronómico del saber, las verdades de hoy se tornan falaces con el amanecer; así, el perfil del receptor se renueva, su inscripción en los textos literarios pasa por el imperativo de la apertura, se lo traza como un ente activo, descodificador, capaz de llenar los vacíos que se le presentan. Noguerol sugiere que en la ironía se necesita establecer la ilusión de distanciamiento frente al lector ${ }^{11}$.

La ironía supone una exhaustiva labor de descodificación y, por tanto, requiere de un receptor versado en el funcionamiento de los procesos de construcción de sentido. Si la sensibilidad moderna se caracteriza por generar apertura y por rechazar las imposiciones ideológicas tradicionales, la ironía y esa capacidad liberadora suya se convierten en herramientas indispensables. Sobre el mismo asunto, Kierkegaard ${ }^{12}$ aporta una característica más: la libertad subjetiva, con la cual se tiene la posibilidad de un comienzo. Así, la ironía no se ve obstaculizada por ninguna circunstancia previa: cuando la leo, me enfrento a ella, me seduce, me of rece la opción de crearla.

La reconstrucción de un enunciado o de un texto irónico, afirma Booth, no se puede reducir a la gramática, la semántica o la linguiística; al leer una ironía nos basamos en las relaciones con los demás, de forma que el lector u oyente hace referencia a sus más profundas convicciones. Aunque las ironías que las personas lean o escuchen se conciban como una pequeña parte de todo lo que las

11 Noguerol, 28.

12 Kierkegaard, 80. 
personas dicen, éstas sacan a la luz complejidades ocultas; al hacerlo, tales abismos pasan a formar parte de la vida ordinaria y se plantean como problemas por resolver. La ironía provoca problemas ya que, como se trata de un ejercicio agresivamente intelectual ${ }^{13}$, fusiona hechos y valores, lo que obliga al receptor a construir jerarquías alternativas y a elegir una. Además, la ironía depende de la existencia de grandes reservas de tacto y experiencia y hasta de sabiduría ${ }^{14}$; el receptor de la ironía requiere práctica, experiencia, una preparación que le permita localizar las ironías y reconstruir su significado. Ahora bien, ¿cómo localizar y descifrar una ironía? Lo primero consiste en saber si debemos o no comenzar la reconstrucción; es decir, en identificar cuándo estamos frente a una ironía.

Para resolver esta serie de enigmas, el receptor debe preguntarse si el autor buscaba la ironía; es decir, si tenía razones de carácter estético, personal o histórico para procurar que el receptor no creyera literalmente en lo que escribía. Con frecuencia, la respuesta no estriba únicamente en elementos extraliterarios; parece probable que se inscriba como parte de la estructura textual; así por ejemplo, la elección genérica impone, para una serie de posibilidades, la inclinación satírica y el empleo de la ironía. Cerremos un poco más la perspectiva - siempre pensando en la manera en que la ironía se convierte en uno de los pilares de ciertos géneros- y centrémonos en la elaboración de un monólogo dramático. Tal creación literaria supone la puesta en marcha de un mundo al revés, con unos personajes que producen impresiones contradictorias. Sin duda, este universo conceptual es coherente con el papel expresivo de la ironía; como consecuencia, , durante todo el monólogo el lector intuye que el fondo y la forma coinciden, ambos promueven la inversión si lo que se desea es acceder a una verdadera comprensión, situada por encima de los sentidos superficiales. El receptor siente confianza para detenerse y esto brota de los propios personajes, de las acciones y de las imágenes, incluso de la argumentación o de los ataques satíricos contra el mundo real.

13 Booth, 78.

14 Booth, 79. 


\section{En torno a la figura del ironista}

El sujeto que expresa la ironía es, para Kierkegaard, negativamente libre. Esta persona o instancia, sea el hablante, el escritor o una figura textual, enuncia lo contrario de lo que piensa; por tanto, es libre con respecto a los demás y de sí mismo, pues su palabra y sus pensamientos no lo sujetan a la transparencia; cuenta con la posibilidad de ocultar, de mentir, de confundir. La negatividad surge porque niega lo que literalmente escribe o dice; puede decir seriamente algo que no es pensado como serio, y en broma una situación muy seria.

Si se considera el retrato propuesto por Noguerol, el escritor irónico, "alienta la complicidad con el receptor cualificado y rechaza al que no percibe las dobles lecturas" 15 ; en pos de semejantes, el ironista rechaza la posibilidad de acercarse al vulgo y promueve una suerte de emancipación de la mente y la comprensión. Al destacar el gesto de suficiencia que adopta el autor irónico ante sus lectores, Kierkegaard afirma tal concepción:

La ironía mira por encima del hombro, por así decirlo, al habla normal y corriente que todos pueden entender de inmediato; viaja de riguroso incógnito [...] Se da principalmente en los círculos superiores, como prerrogativa que pertenece a la misma categoría que el «bon ton» que obliga a sonreír ante la inocencia y a considerar a la virtud como una especie de mojigatería ${ }^{16}$.

Con esa figura se da por sentada la existencia de una fraternidad de la inteligencia; su acción semiótica aboga por lectores capaces de sortear sus trampas. Ante esto, Booth señala que "es mucho más importante la instauración de comunidades amistosas que la exclusión de víctimas ingenuas" ${ }^{" 17}$. No obstante, esta perspectiva no resulta

15 Noguerol, 27.

16 Kierkegaard, 246.

17 Booth, 57. 
frecuente entre los propios ironistas. Mucho más próximo al sentido de la ironía en este aspecto, Kierkegaard considera que "hay tan poco de camaradería en una congregación de ironistas como de verdadera lealtad en una república de ladrones" ${ }^{18}$. Como resultado de este proyecto de apología de la agudeza, los mismos escritores o hablantes gozan en su soledad de los engaños que procuran; así, "cuanto mayor es el engaño que el ironista consigue, cuanto más prospera su falsificación, tanto mayor es su satisfacción. Pero goza de esa satisfacción en total soledad, y de él depende precisamente que nadie descubra su impostura" 19 .

¿Cómo se concibe la relación entre el ironista y los no iniciados? Hemos dicho que el ironista establece una conexión entre él y los receptores que comprenden su obra o enunciado, una relación de complicidad. Sin embargo, el ironista no puede poseer un vínculo con los que no comprenden su humor, con los no iniciados, con las personas contra quienes va dirigida su polémica altanería. Kierkegaard comenta este asunto y concluye que esa no relación provoca, en el escritor, dos alternativas o posibles actitudes:

[...] o bien el ironista se identifica con la aberración que quiere combatir, o bien se coloca en una relación de oposición con respecto a la misma, siendo siempre, naturalmente, consciente de que su apariencia es lo opuesto a aquello a lo que él mismo se atiene con firmeza, y goza satisfecho de esa desproporción ${ }^{20}$.

Este vínculo del ironista con la persona que no capta sus ironías se vuelve muy estrecho cuando el escritor o hablante le hace entender a la otra persona que cayó en la trampa del sentid. El ironista busca por doquier las debilidades de sus receptores, eso lo vuelve superior a ellos e incluso le permite manejarlos a su antojo. De esta manera,

$\overline{18 \quad \text { Kierkegaard, }} 76$.

19 Ídem.

20 Kierkegaard, 76. 
una de las grandes satisfacciones del ironista es la de detectar por doquier esos rasgos de debilidad; y cuanto más listo es aquel que los posee, tanto mayor es su satisfacción cuando logra burlarlo, tenerlo en su poder sin que él mismo lo advierta, de manera que hasta un individuo listo resulta, por momentos, como un muñeco que el ironista sostiene de un hilo, una marioneta que puede manejar como sea y como le parezca con solo tirar del hilo ${ }^{21}$.

Se plantea otra característica del ironista: mediante su postura ante la vida y mediante sus escritos, manipula al oyente o lector y crea una relación similar a la de un Dios con su creación, a la de un titiritero con su fantoche. Incluso, los personajes de las obras del ironista pueden convertirse en sus marionetas y, sin intención o con ésta, reflejar los vicios de una determinada sociedad.

La relación poco fraternal con las personas que no comprenden su obra y el gozo al saber que los puede manipular como marionetas, responde, en la obra de Freud, a un impulso del carácter, el sentimiento de superioridad ${ }^{22}$; el autor de la obra irónica mira a los demás como inferiores. El ironista goza de una total libertad, y la expansión que muchos buscan en confidentes, él la consigue con sólo confesar que no sabe nada.

\section{En torno a la tipología de la ironía}

Si bien este tema lo han analizado muchos teóricos, existe un acuerdo: por regla casi general, la categorización de la ironía ha sido dual. Una tipología, muy importante como punto de partida para el análisis del discurso irónico la encontramos en la obra de Booth; este estudioso de la retórica clasifica la ironía mediante dos categorías: estable e inestable.

$21 \quad$ Kierkegaard, 77.

22 Freud, 212. 


\section{La ironía estable}

Booth construye el concepto de ironía estable a o largo de casi toda su obra; sin embargo, brinda, entre otras notas menos explicativas, la siguiente noción concreta para referirse a ésta:

[La ironía estable] es una estructura de significados, una orden que elimina algunas lecturas haciéndolas parecer como enteramente erróneas, hace ver que algunas otras lo son parcialmente y confirma otras como más o menos adecuadas. Aunque nadie puede tener la esperanza de acertar plenamente a no ser que se trate de las ironías más sencillas ${ }^{23}$.

Booth propone cuatro pasos para reconocer una ironía estable. A estas cuatro etapas les llama Los pasos de la reconstrucción; estos son:

1. Primer paso: el lector rechaza el significado literal del enunciado.

2. Segundo paso: se ensayan explicaciones o interpretaciones alternativas.

3. Tercer paso: se toma una decisión sobre los conocimientos o creencias del autor.

4. Cuarto paso: el lector elige un significado o conjunto de significados que presume acertado.

2. La ironía inestable

Booth compone el concepto de ironía inestable mediante el contraste con la estable: mientras en esta última resulta factible alcanzar una reconstrucción del sentido, en la inestable, de la verdad que se afirma o queda implícita no se puede elaborar, a partir de la ruinas reveladas por medio de la ironía, una restauración consistente. La clave es que el enunciatario se distancia, se niega a declararse a favor de una proposición estable; no desea que el significado de sus

23 Booth, 306. 
palabras simplemente sea descifrado mediante la inversión del enunciado o la exploración; su pretensión estriba en provocar incertidumbre, en interrogar o hacernos comprender que la duda se impone y que toda labor hermenéutica envuelve una empresa imposible. Por regla, la ironía inestable supone la acumulación de enunciados ambiguos; surge como resultado de la significación total del texto y no del sentido cifrado de un segmento; en suma, implica un alto grado de apertura de la obra literaria.

\section{En torno a las relaciones entre la ironía y la sátira}

La ironía y la sátira son elementos que muestran diferencias entre sí; sin embargo, se relacionan o, aun mejor, pueden coincidir en una obra o discurso sin contradecir su carácter irónico o satírico. Antes de establecer los diferentes niveles en que tal figura expresiva se asocia con tal función poética, lo primordial sería definir qué es la sátira. De acuerdo con el Diccionario de retórica, crítica y terminología literaria:

[...] es un género literario en verso, en prosa o en prosa y verso (sátira menipea) de carácter polémico, crítico-moralizador o irónico, que tiene como objeto la representación de la realidad cotidiana en alguno de sus infinitos aspectos seriocómicos: los defectos de los hombres, las fantasías de los rastacueros, los vicios de los ricos, los sucesos más o menos memorables de la vida, etc. El origen de la palabra satura — que probablemente quería decir "plato colmado» de diversos alimentos- hace pensar en una festividad religiosa durante la cual se of recía a la divinidad, Deméter - Ceres-, un plato de primicias, con acompañamiento de cantos, danzas y escenas no exentas de sabrosas salidas. La sátira tendría, pues, un origen folklórico-cultural ${ }^{24}$.

24 Marchese y Forradellas, 360. 
Noguerol defiende la idea de que el término sátira no es un concepto acabado, ya que a través del tiempo ha sido empleado con muy variadas acepciones. Para Bajtín, por ejemplo, implica la existencia de un género con rasgos distintivos — la sátira menipea—; para Dostoievski, este término debe utilizarse para denominar una especie de género periodístico propio de la Antigüedad Clásica. Si se atienden ambos casos, la sátira fluctúa entre lo ensayístico, lo burlesco, lo paródico y lo narrativo; al final, se concluye que se la concibe como "un camaleón de forma cambiante y de infinita variedad"25; en nuestros días, una suerte de modo, aspecto del contenido o de la intención de la obra.

El escritor satírico mantiene una actitud de invectiva frente a la humanidad, ataca en diversos grados de severidad los defectos de ésta. Con frecuencia, se insiste sobre el valor moralizante de la sátira; desde esta perspectiva, su función depende, en exclusiva, de coyunturas histórico-sociales; no obstante, las obras satíricas que sobreviven son algo más que documentos de época: "enf atizan la manipulación de que han sido objeto las circunstancias externas en la literatura y recalcan el valor artístico del producto final" 26 .

Según Booth, la ironía puede hallarse sin duda en la sátira; incluso, cierta ironía es satírica. Sin embargo, gran parte de la ironía no deviene en sátira. La sátira irónica, quizás el género más conocido de todos cuantos recurren a la ironía, tiene una particular condición: el lector no se detiene hasta daqr con un conjunto de mensajes convincentes o de ataques satíricos contra una creencia, persona o cosa perteneciente al mundo real; este conjunto de enunciados opera bajo la forma de ofensiva encubierta ${ }^{27}$. La ironía agrupa a las personas que comprenden su mensaje; poco a poco, funda pequeñas comunidades amistosas, camadas de cómplices que se identifican con lo que leen o escuchan. La sátira no pretende gregarismos, el satírico no tiene

\begin{tabular}{ll}
\hline 25 & Noguerol. 23. \\
$\therefore$ & Noguerol. 25. \\
$\therefore$ & Booth. 190.
\end{tabular} 
bando, arremete contra toda postura; mientras el ironista rechaza todo, excepto la inteligencia, el hacedor de la sátira se vuelve contra todo, incluso contra la capilla creada por el ironista.

Booth afirma que la ironía no busca víctimas. Si un mal lector cae en la trampa tendida, se debe a su reducida capacidad para reconstruir el significado. La ironía misma no lo excluye, lo hace él mismo; caso contrario, la sátira sí se burla del lector. En la ironía no hay sarcasmo, sí en la sátira.

\section{En torno a las relaciones entre ironía y parodia}

$\mathrm{Al}$ igual que en el caso de la sátira, el concepto de parodia ha originado confusión. Lo más sensato sería examinar algunas de las principales definiciones. De acuerdo con Bajtín:

[...] la parodia implica la creación de un sosia que «destrona» al héroe principal, la afirmación de un «mundo al revés»; como la sátira, parece estar unida en sus orígenes a lo cómico carnavalesco [...], en el que cada uno de los valores jerárquicos tradicionales se desacraliza, se escarnece y se derrumba. En un sentido más amplio, se produce la parodia cuando la imitación consciente y voluntaria de un texto, de un personaje, de un motivo se hace de forma irónica, para poner de relieve el alejamiento del modelo y su volteo crítico ${ }^{28}$.

Para Freud, la parodia alcanza el rebajamiento de lo sublime mediante la destrucción de la unidad de los caracteres que nos resul$\tan$ familiares en ciertas personas y en sus dichos, así como en sus acciones. La parodia también puede sustituir a las personas sublimes y sus características por unas de inferior nivel.

En Palimpsestos, Genette dedica un capítulo al recuento de la historia del concepto. Desde una perspectiva etimológica, el vocablo

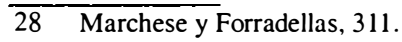


parodia proviene de la adicción de dos voces griegas: “[...] ôda, es «canto»; para, «a lo largo de», «al lado»; parôdien, de ahí parôdia, sería el hecho de cantar de lado, cantar en falsete, o con otra voz, en contracanto - en contrapunto-, o incluso cantar en otro tono: deformar, pues, o transportar una melodía" 29 .

$\mathrm{Si}$ se atiende a este sentido primigenio, es probable que la parodia haya empezado como parte de la oralidad; se refuerza tal hipótesis cuando se constata que no se conservan rastros escritos de parodias primitivas.

Aristóteles dio, además, con una obra titulada Deilíada, compuesta por Nicocares; su nombre procede del griego deilos, 'cobarde'; es decir, una Ilíada de la cobardía. Al parecer, buena parte de las parodias escritas durante la Antigüedad clásica entrañaban el propósito expreso de mofarse de las epopeyas, de ridiculizar a los héroes; por esto, más adelante — demasiado tarde, en opinión de Genettese instaurará un género literario denominado poema heroico-cómico, en el que el protagonista actúa como un pusilánime; el escarnio desemboca en una risa que libera al hombre ordinario, parte del auditorio, de los modelos extraordinarios ${ }^{30}$.

La parodia arranca entonces de la época en que los rapsodas cantaban las formas orales de lo que luego serían la Ilíada y la Odisea. Si durante el transcurso de sus interpretaciones el público llegaba a cansarse de seguir el relato, los poetas introducían breves poemas, similares en el estilo pero que provocaban sentidos distintos; lo hacían para que el público se divirtiera y animara de nuevo. Junto a esto, intervenían los bufones: cuando el rapsoda terminaba, estos cómicos jugaban a invertir los personajes de las historias recién concluidas con el único objetivo de suscitar la risa.

Para Booth, en la parodia el lector descubre una referencia externa curiosamente duplicada, pues el receptor de la obra recurre a la referencia exterior de otros autores para comprender la forma en que

29 Gerard Genette, Palimpsestos (Madrid: Taurus, 1989) 20.

30 Genette, 22. 
la parodia ataca a esos mismos autores; es decir, a lo que nos remitimos externamente para facilitar la comprensión es el objeto de ridículo, por ejemplo, una obra famosa.

En resumen, la parodia toma un acontecimiento o elemento unitario y lo manifiesta en su sentido opuesto; así rebaja a los personajes y conduce todo el problema hacia lo cómico. Noguerol apoya esta noción de parodia, pues la considera "una forma de sátira en la que se imita y desfigura el estilo de la víctima"31.

\section{En torno a lo cómico y su relación con la ironía}

Para discurrir acerca de lo cómico, se vuelve necesario referirnos al humor; éste es, para con Freud, una de las variedades de lo cómico. En el Diccionario de términos literarios, se describen algunas de las acepciones asignadas, por la tradición cultural, al vocablo humor:

Según el griego Hipócrates (s. V a. C.), en el cuerpo humano se mezclaban cuatro humores (es decir, cuatro líquidos) relacionados con los cuatro elementos o sustancias de que está formado el universo: la bilis amarilla con el fuego, la atrabilis o bilis negra con la tierra, la sangre con el aire y la flema con el agua. El comportamiento moral y el temperamento de cada hombre dependía de la relación con que estuviesen mezclados los humores y del predominio de uno o de otro, y así resultaban el colérico, el melancólico, el sanguíneo y el flemático. Durante la Edad Media el término humor fue usado según esta tradición hipocrática [...] El humor, según lo entendía Freud, es una forma liberadora de enfrentarse al mundo y de rechazar sus agresiones, y, como tal, y no exento a veces de un cierto dolor íntimo, ha impregnado desde siempre la literatura de todos los países. ${ }^{32}$

$31 \quad$ Noguerol, 157.

32 Platas Tasende, 382. 
En este ensayo dejamos de lado la concepción antigua, debido a nociones en desuso; la concepción de Freud predomina en esta breve exposición, pues justamente of rece una idea de hombre moderna. De acuerdo con las aseveraciones del padre del Psicoanálisis, el humor es una de las apreciaciones psíquicas más elevadas; más aun, goza del favor de los pensadores. Las variedades del humor son diversas, según sea la naturaleza de la excitación de sentimiento: compasión, enojo, dolor, enternecimiento u otro ${ }^{33}$. Así, cuando los artistas intentan domeñar otros sentimientos a favor del placer humorístico y lo logran, instauran nuevas formas de humor.

Lo cómico se produce, primero, como un hallazgo no buscado entre los seres humanos en sus vínculos sociales; se lo descubre en las personas, en sus movimientos, formas, acciones y rasgos del carácter. Luego, los animales y objetos inanimados pueden ser concebidos como cómicos. El placer cómico lo constituyen varios aspectos: el primero es que su génesis resulta ser la voluntad alegre general, es decir, cuando la persona está proclive a reír. El segundo es la expectativa de lo cómico; la persona que va a leer u observar una obra cómica ríe por el recuerdo de haber reído, por la expectativa de reír. El tercero se refiere a un elemento que entorpece lo cómico; todas las modalidades del proceso de pensar lo bastante distanciadas de lo intuible $^{34}$. El cuarto aspecto consiste en otro elemento que distrae la comicidad: el decoro; un profesor de danza no reiría de los movimientos torpes de sus nuevos estudiantes. El quinto muestra cómo la comicidad no puede surgir cuando hay un desencadenamiento de afecto; en otras palabras, no puede darse cuando están incluidos sentimientos o intereses intensos. Y el último aspecto manifiesta que el placer cómico puede ser promovido por cualquier otro elemento placentero.

Umberto Eco comenta el paso de lo cómico en la vida - lo hemos estado analizando de la mano con Freud-a lo cómico en el texto; el bisel entre uno y otro ocurre cuando:

33 Freud. 219.

34 Freud. 208. 
[...] hemos salido de la esfera de lo fisiológico: el que riamos es signo de que se ha puesto en marcha un cierto mecanismo, pero el mecanismo produce su propia catarsis, porque nos sentimos llevados a preguntarnos por qué ese texto ha conseguido hacernos reír ${ }^{35}$.

Lo cómico se relaciona, entre otras cosas, con la ironía porque puede manifestarse como lo contrario; eso produce la risa; además se origina lo que Pirandello llamó un sentimiento de lo contrario. Para pasar de lo cómico al humor, afirma Eco, debemos renunciar a los sentimientos de separación y superioridad, características propias de lo cómico. Esta superioridad se relaciona con la ironía; el ironista mira por encima del hombro — como afirma Booth — a sus lectores; con lo cómico, las personas ríen porque no se ven envueltas en el error o la broma. El receptor de la obra (es decir, el lector) no puede verse aludido por la broma: para reír de ella debe reflejarla en otro u otros; si la ironía lo incluye no podrá reír con los demás; sobre esto, Umberto Eco rememora cómo:

Para Kant, la risa nace cuando se produce una situación absurda que hace que quede en nada una expectativa nuestra. Pero para reír de ese «error» es necesario, también, que el error no nos involucre [...]. Para Hegel, resulta esencial para lo cómico que el que se ríe se sienta tan seguro de su verdad que pueda mirar con superioridad ${ }^{36}$.

La ironía produce en el lector una risa [que es] completa si no se refiere a él, si no lo alude. Sucede lo mismo que con el chiste; según la interpretación psicoanalítica, éste se ocupa siempre de un tercero, distinto del emisor y el receptor. En relación con el tema de

35 Umberto Eco, Entre mentira e ironía (Barcelona: Lumen, 1998) 74-75.

36 Eco, 80. 
lo cómico, Eco determina una regla fundamental: "He sostenido siempre que los dibujantes se dibujan en sus protagonistas" 37 .

Para Freud, la caricatura sirve de nexo entre el chiste y lo cómico, pues se levanta contra la autoridad y nos hace reír sólo porque le adjudicamos el mérito de enfilarse contra lo serio y lo establecido. La caricatura permite a una persona volverse graciosa, la sitúa en un nivel distinto pues al cambiar su expresión, cambia también la manera en que se la percibe. El resultado es interesante porque se pone el acento en la dimensión material del individuo, en su corporeidad; sin embargo, esta técnica se alía a tendencias hostiles y agresivas, ya que el autor puede tomar a sus personajes y hacerlos despreciables con el propósito de disminuir sus títulos de dignidad y autoridad; el defecto se entiende como sinónimo del vicio cuando se opera bajo esta tendencia.

La caricatura y lo cómico están estrechamente relacionados. Los personajes de una obra se representan como caricaturas con el fin de producir comicidad, a veces cercanía o afabilidad, pero también para destacar sus excesos, su condición mortal e ingenua, para burlarse por medio de ellos de la sociedad y transformar las "leyes" que le impiden crear situaciones nuevas.

La caricatura opera mediante el rebajamiento. Su mecanismo predilecto consiste, según Freud ${ }^{38}$, en realzar la expresión global del objeto sublime; es decir, en sobredimensionar un rasgo único que es en sí cómico y que al apreciarse como parte de la imagen total, por regla, pasa inadvertido. Esta característica de la caricatura, la exageración, conlleva la construcción de una imago de la desmesura. Un elemento esencial del origen del placer es que el efecto de la caricatura no sufra un menoscabo por el falseamiento de la realidad; algo debe de haber alrededor que confirme que se vive en un mundo sin límites, de excesos; la risa se ampara en el mecanismo de la imitación.

$37 \quad$ Eco, 131.

38 Freud, 191. 
Noguerol define la caricatura como una técnica trascendental para la sátira, y como una "representación peyorativa de un individuo a través del énfasis en sus rasgos más desagradables [...], donde los individuos son ridiculizados a través de sus acciones, lenguaje, hábitos y pensamientos" 39 .

\section{La ironía, la sátira, la parodia y lo cómico como formas de subversión}

Todas estas líneas de escritura son estrategias de insurrección contra la cultura, el sentido cultural, por medio de la risa. La risa desempeña un papel trascendental en la consecución de los enunciados de la ironía, la sátira, la parodia y lo cómico. Cuando el receptor de alguna de ellas logra reconstruir el significado y comprende la idea oculta tras las palabras, se convierte en el cómplice del creador y la risa surge como la conclusión de dicho trance, constituye una suerte de alianza entre ambos, a veces buscada, a veces fortuita.

Panero describe dos tipos de risa: por una parte, la irónica, un movimiento moral; por otra, la humorística; absolutamente amoral. La risa irónica le merece el calificativo de risa de las cadenas; la humorística, el de risa de la revolución ${ }^{40}$. La risa de la ironía es moral, pues desciende sin llegar hasta el fondo de las ideas, se ríe cuando las costumbres no están de acuerdo con las convenciones; es decir, cuando su creación no calza con las costumbres sociales (canon de la cultura), con el llamado "sentido común".

Panero concibe la ironía — aunque quizá su alusión se refiera más exactamente a un tipo de ironía (la estable) que a la ironía misma-como la esencia del "reírse de"; es decir, me río porque estoy en lo correcto, porque no soy imperfecto, porque mi comportamiento es intachable. Caso contrario, el humor — la ironía inestable-supone

39 Noguerol, 228.

40 Leopoldo María Panero, Prólogo a Matemática demente, de Lewis Carroll (Barcelona: Tusquets, 1999) 46. 
la esencia de la risa, de la abolición del orden; ésta expresa el regocijo por ser completamente imperfecto.

El ironista rígido —el que emplea la ironía estable — castiga con la risa, su risa es represiva; como propone Freud, la emplea como defensa frente a un placer excesivo ${ }^{41}$. La punición se dirige contra aquello que deja de ser lo que debería ser, a las costumbres cuando cambian su formulación, al individuo que, obedeciendo a sus malas inclinaciones, excede al Yo, al Otro. La risa de la ironía estable se muestra como una risa entre dientes: una risa acorralada por las Ideas. Como contraparte, la risa del humor - la causada por la ironía inestable - se manifiesta "total y pura: libre de toda cadena", es "la risa porque sí, la carcajada del loco. El reírse solo. La risa que encuentra en sí misma su propia causa, que se sustenta sobre sí misma",42.

Panero reafirma que la ironía estable permanece en un movimiento vertical, donde el punto más importante está arriba — signo imprescindible del ironista, reflejo de su sentimiento de superioridad-; cuando esto ocurre, la risa es "vacua, lejana e ineludible de los cielos; una risa con la que la religión se disfraza" ${ }^{33}$. Por el contrario, el humor desconoce toda profundidad o altura; su movimiento ocurre en la superficie, pero esta superficie no es plana, sino más bien quebrada; para esta superficie, la profundidad es escasamente exten$\mathrm{sa}^{44}$. El humor - si se sigue nuestra formulación, la ironía inestabletiene un movimiento horizontal pero no posee centro - como sí lo tiene la estable-. Muestra Panero el humor como una rueda que gira alrededor de ningún centro, una caja sin fondo, algo que carece del yo, algo que ignora las ideas y el lenguaje que las genera. La ironía estable obra por medio de ejemplos; la inestable, por abruptas designaciones; una designación que no es categoría lingüística, no forma parte del discurso; más bien, lo excluye.

\footnotetext{
$41 \quad$ Panero. 41.

42 Panero, 44.

43 Panero, 41.

44 Ídem.
} 
Panero continúa su diferenciación entre la ironía y el humor: la ironía - estable - hace de un sin sentido (la risa) el medio para instaurar el significado; el humor —ironía inestable - es, en cambio, comunicación plena (fusión de sentido y sin sentido); en el primer caso, se contrasta el sin sentido con el significado; en el humor prevalece un acuerdo de recíproca disolución ${ }^{45}$. La ironía trabaja por medio del lenguaje; en las antípodas, el humor es el arte de la forclusión, es decir, arte de acallar.

Una de las formas más representativas de la risa que se enfrenta a la razón, anotan D'Angeli y Paduano, suele ser la utilización extrema del instrumento lingüístico en contra de la función social y pragmática que le es atribuida ${ }^{46}$. No es extraño que en la literatura cómica tenga lugar el ataque directo a los procedimientos lógicos del lenguaje, pues se aplican al universo de los enunciados negativos las propiedades válidas de los positivos, un procedimiento prohibido por la lógica clásica y que se asemeja a la ironía.

Para D'Angeli y Paduano, lo cómico tiene una vertiente fundamental, la trasgresión; lo cómico trasgresor se refiere a la rebelión del hijo impelido por la represión del padre. De esta manera,

la trasgresión más clamorosa, que no admite atenuante y se presenta como insubordinación autónoma, vivida como absoluto placer y espíritu de juego, solo se da cuando no es más que una fachada de malas intenciones yuxtapuesta a acciones objetivamente buenas ${ }^{47}$.

El enfrentamiento entre padre e hijo lleva a la despenalización de la trasgresión juvenil ${ }^{48}$. La conciencia ética del destinatario concede indulgencia al pecador, disimula la afrenta al mundo de lo adulto,

$45 \quad$ Panero, 43.

46 Concetta D’Angeli y Guido Paduano. Lo cómico (Madrid: Machado Libros, 2001) 21.

47 D' Angeli y Paduano, 132.

48 D'Angeli y Paduano, 132. 
lo serio y lo racional; esto provoca una risa doble: por el pecado y por la necia voluptuosidad (una risa moral y una amoral). Con esta metáfora en mente, Panero señala que para los humoristas ni siquiera existe un padre; lo mismo sucede con los esquizof rénicos, no pueden ser domesticados por medio del Edipo: se pueden concebir a sí mismos como Dios, un dios burlón y taimado que no toma nada con gravedad, ni siquiera con prudencia.

La ironía satiriza la realidad, trata de cambiar el estado de las cosas por otro orden mejor, ideal; su afán radica en reformar las costumbres: castigat ridendo mores. La ironía es por naturaleza reformista. El humor, por su parte, desconoce por completo la realidad; con él se quisiera instaurar una revolución, atenta contra el sentido de realidad y contra cualquier clase de costumbre; es decir, instaura el orden del caos, lo absoluto extramoral. La ironía se manifiesta como resentida y dolorosa, trágica. El humor se sitúa más allá de lo cómico y lo trágico.

Las risas en la ironía y en el humor nos llevan, indiscutiblemente, a emparentar ambos conceptos con los de ironía estable e ironía inestable; así pues, la risa de la ironía estable (ironía) se muestra como moralizante y la risa de la ironía inestable (humor) no tiene ningún sentido, nos lleva al silencio, a la Nada; tal como explica Freud, a la palabra que habla de la imposibilidad de la palabra, a, como la llaman los pedagogos, la disonancia cognitiva. El ironista tiende a crear, o mejor dicho, a destruir — con la ironía inestable o el humor- su mundo real, las Ideas que gobiernan a los demás. Tiende a disparatar la construcción ideológica, las creencias de sus lectores u oyentes.

Ese placer de disparatar — como lo denomina Freud ${ }^{49}$ — está oculto en los adultos como consecuencia de la represión ejercida sobre el discurso. El disparate, lo absurdo no nace al azar de una mezcla de elementos, puede ser enderezado por medio del inconsciente; eleva el gasto psíquico del oyente e incrementa el monto en que se libera mediante la descarga de la risa. El antiguo placer que se experimentó

$\overline{49 \quad \text { Freud, } 120 .}$ 
con el disparate en la niñez puede ser revivido por la acción del chiste, y por ende, por la ironía, la sátira, la parodia y la comicidad.

Este proceso de liberación de energía psíquica conlleva a subversión, pero también al supremo aprendizaje: saber acerca de las restricciones epistemológicas y personales. Mientras la ironía estable trata de cambiar al lector por medio de su manera de manifestar el significado real, la ironía inestable no pretende cambiar al lector. Su significado no es uno sino varios; cada vez que el lector considere que encontró el correcto, vendrán otros detrás de ese. Tras esto, se esconde la fuerza humana que se opone a la razón, incluso, la razón misma, pues ésta posee la capacidad de hacerse cargo de instancias que le son extrañas. 